\author{
Aleksander Sroczyński \\ „Artes Liberales”, UW, Warszawa \\ a.sroczynski@al.uw.edu.pl
}

\title{
Funkcje pamięci o sporze Benedykta Herbesta z Jakubem Górskim i arbitrażu Stanisława Orzechowskiego („Wawrzyńca z Sieradza”)1
}

\section{Abstract \\ The Functions of Remembering the Dispute between Benedict Herbest and Jakub Górski, as well as the Arbitrage of Stanisław Orzechowski ("Wawrzyniec z Sieradza")}

The article discusses the history of reception of the dispute between Benedykt Herbest and Jakub Górski in old-Polish culture. Particular focus is given to the role played in the dispute by its arbiter, Stanisław Orzechowski, who used the pseudonym of Laurentius Siradiensis (Wawrzyniec of Sieradz) for that occasion. The special relation and fascination of Benedykt Herbest with the figure of Orzechowski is described basing on two texts of Herbest: Periodicae responsionis libri V and Wypisanie drogi (The Description of a Journey). The next stage of the reception of the dispute was the works of Szymon Starowolski De claris oratoribus Sarmatiae and Scriptorum polonicorum hekatontas, in which the dispute of the Cracow professors gained a rank of a praiseworthy achievement of the „Sarmatian” oratory.

1 Problemom historii sporu Górskiego i Herbesta ze szczególnym uwzględnieniem roli, którą odegrał w nim Orzechowski, poświęciłem rozprawę magisterską napisaną pod kierunkiem prof. Andrzeja Borowskiego na Wydziale Polonistyki UJ. $\mathrm{W}$ niniejszym studium wykorzystuję przeredagowane fragmenty tego magisterium. 
Franciscus Richardus Goezius can be put in opposition to Starowolski. In his collection of historicoliterary essays Otium Varsaviense, he presented the course of dispute quite diligently, but did not conceal his dismissive attitude toward the merit of dispute. This is characteristic of the approach of Enlightenment elites towards too pedantic, from their point of view, rhetorical discussions of the Renaissance.

Key words: cultural memory, rhetoric, intellectual disputes, Benedykt Herbest, Jakub Górski, Stanisław Orzechowski, Franciscus Richardus Goezius.

Spór Benedykta Herbesta z Jakubem Górskim o naturę i właściwą metodę konstruowania cycerońskich periodów doczekał się analizy zarówno jego przebiegu, jak i teoretyczno-retorycznej istoty ${ }^{2}$. Aby jednak doktrynalna strona sporu mogła zostać właściwie naświetlona, musiała czekać na odrodzenie się zainteresowań retoryką w XX wieku. Celem niniejszego studium nie jest powiększenie wiedzy $\mathrm{w}$ tym zakresie; ma ono natomiast na celu przybliżenie na wybranych przykładach tego, jak kształtowała się i jaką funkcję pełniła staropolska pamięć o tym sporze. W artykule skupię się na trzech grupach tekstów, które przypominają konflikt. Pierwszą stanowią dzieła samego Herbesta Wypisanie drogi i Periodicae responsionis libri $V$, na drugą składają się pisma Szymona Starowolskiego Setnik pisarzów polskich i $O$ znakomitych mówcach Sarmacji, ostatnią zaś praca jest osiemnastowieczny traktat Otium Varsaviense (Wrocław 1755) pracującego w Bibliotece Załuskich Franciszka Ryszarda Goeziusa. W toku analizy przedstawię właściwe poszczególnym autorom strategie upamiętniania ${ }^{3}$ konfliktu dwóch krakowskich profesorów wymowy.

2 A. Werpachowska, $Z$ dziejów retoryki XVI wieku. Polemika Jakuba Górskiego $z$ Benedyktem Herbestem, Wrocław 1987.

3 Ogólnie o problemach pamięci zob. P. Ricoeur, Pamięć, historia, zapomnienie, przeł. J. Margański, Kraków 2006; J. Le Goff, Historia i pamięć, przeł. A. Gronowska, J. Stryjczyk, Warszawa 2007. Inspiracją do podjęcia refleksji nad funkcjami pamięci i niepamięci była dla mnie książka J. Assmann, Pamięć kulturowa. Pismo, zapamię- 


\section{Spór}

Jakub Górski wydawał, począwszy od 1558 roku, opracowania poszczególnych części elokucji; składały się na nie trzy podręczniki: De periodis atque numeris oratoriis, De generibus dicendi $i^{4}$ oraz De figuris tum grammaticis, tum rhetoricis. Początkowo nic nie zapowiadało konfliktu między krakowskimi profesorami, łączyły ich serdeczne stosunki, a dwa ostatnie $\mathrm{z}$ wymienionych traktatów zostały poprzedzone przez Herbesta wierszami. Ich relacje jednakże pogorszyły się, gdy Herbest wystąpił z odmienną od głoszonej przez Górskiego teorią periodu retorycznego. Uczynił to najpierw w swojej edycji listów Cycerona M. Tulli Ciceronis epistolarum libri IV i w trakcie wykładów w semestrze letnim 1561 roku. Górski, nie mogąc skłonić młodszego kolegi do odwołania poglądów, wyzwał go na publiczną debatę, którą w swoim mniemaniu wygrał. Herbest natomiast nie uważał się za przegranego i kontynuował swoje wykłady, co doprowadziło do kolejnej dysputy (5 grudnia 1561 roku), która jednak nie odbyła się z powodu choroby Herbesta. Dalsza wymiana poglądów toczyła się za pomocą druku. Herbest ogłosił w 1562 roku rozprawę zatytułowaną Periodica disputatio, na którą Górski odpowiedział traktatem Disputationis de periodis contra se a Benedicto Herbesto (si Diis placet) Neapolitano editae refutatio. W 1566 roku pedagog z Nowego Miasta na Rusi podsumował spór dziełem Periodicae responsionis libri $V^{5}$.

Głos w dyskusji zabrało wielu znanych pisarzy. Po stronie Herbesta opowiedział się Grzegorz z Sambora. Herbest próbował do oceny sporu włączyć Andrzeja Patrycego Nideckiego, Piotra Skargę i Stanisława Orzechowskiego. Górski zdołał sobie zapewnić poparcie

tywanie i polityczna tożsamość $w$ cywilizacjach starożytnych, przeł. A. Kryczyńska-Pham, Warszawa 2008.

4 Jako jedyny doczekał się współczesnego wydania, J. Górski, De generibus dicendi / O rodzajach wymowy, przeł. i oprac. R. Sawa, red. nauk. A. Axer, Warszawa 2010.

A. Werpachowska, $Z$ dziejów retoryki..., s. 20-23. 
pisarzy tej miary, co Jan Kochanowski, który przekuł wyrok Filipa Padniewskiego w łaciński epigramat (foricenium 49) ${ }^{6}$, młody Wawrzyniec Goślicki ${ }^{7}$ czy wreszcie Stanisław Orzechowski w Dissertatio Laurentii Siradiensis z 1563 roku. Orzechowski postąpił z prośbą o arbitraż dość osobliwie. Wypowiedział się bowiem pod pseudonimem „filozofa” Wawrzyńca z Sieradza i jednoznacznie rozsądził spór na korzyść Górskiego. Miał on za złe Herbestowi, jak się zdaje, zbytnie zbliżenie rytmu prozy ułożonej według proponowanych przez niego zaleceń do poezji ${ }^{8}$.

Istotą sporu między dwoma cyceronianistami była różnica postaw względem uczenia konstruowania periodów: Górski był wyznawcą tradycyjnie przyjętej wśród humanistów metody imitacyjnej, Herbest miał natomiast ambicje wywieść ścisłe reguły budowy periodu z pism Cycerona. Odnośnie do samej warstwy teoretycznej starszy ze skonfliktowanych profesorów uważał, że aspekt syntaktyczny i rytmiczny są ze sobą nierozerwalnie związane, a nauczyciel $\mathrm{z}$ Nowego Miasta na Rusi wprowadził $\mathrm{z}$ kolei w swoich analizach nowatorski podział na struktury składniowe, zorganizowane zgodnie

6 Zob. E. Buszewicz, Wielcy i mali poeci w „Foricoeniach” Jana Kochanowskiego, w: Dobrym towarzyszom gwoli. Studia o „Foriceniach” $i$ „Fraszkach” Jana Kochanowskiego, red. R. Krzywy, R. Rusnak, Warszawa 2014, s. 76-80; M. Mejor, Jana Kochanowskiego foricenium "Ad Iacobum Gorscium”, czyli kim był Helvidius, w: Wiązanie sobótkowe. Studia o Janie Kochanowskim, red. E. Lasocińska, W. Pawlak, Warszawa 2015, s. 166-181.

7 Jako autor stemmatu towarzyszącego Dissertatio Laurentii Siradiensis.

8 A. Werpachowska, $Z$ dziejów retoryki..., s. 130. O funkcji tego pseudonimu w kontekście staropolskiej kultury retorycznej zob. A. Sroczyński, Dylematy Stanisława Orzechowskiego wobec staropolskiej kultury retorycznej, w: Literatura renesansowa $w$ Polsce i Europie. Studia dedykowane Profesorowi Andrzejowi Borowskiemu, red. J. Niedźwiedź, Kraków 2016, s. 359-361. Szerzej o konflikcie w kontekście sporów europejskich zob. S. Łempicki, Spory i turnieje literackie epoki renesansu, w: idem, Wiek złoty i czasy romantyzmu w Polsce, Warszawa 1992, s. 120-148, zwłaszcza s. 135-148. 
z semantyką i retoryczne rządzące się intonacją. Do tego dochodziło jeszcze wiele kwestii szczegółowych?

\section{Niepamięć Herbesta}

Musimy na wstępie stwierdzić, że wyrok, jaki wydał Orzechowski w sprawie sporu Herbesta z Górskim, był dla bakałarza z Nowego Miasta bolesnym doświadczeniem. Co więcej, brak bezpośredniej odpowiedzi kanonika przemyskiego na prośbę o zabranie głosu w sporze mógł być dla niego dodatkową przykrością ${ }^{10}$. Jak się przekonamy, Herbest nie przyjął do wiadomości oceny Orzechowskiego, co wiązało się z jego głębokim podziwem i fascynacją postacią kanonika przemyskiego. Można zadać pytanie: czy Rozprawa Wawrzyńca $z$ Sieradza znalazła jakiś oddźwięk w twórczości Benedykta Herbesta? Ponieważ kwerenda nie pozwoliła odnaleźć w jego pismach bezpośrednich odwołań do retorycznego opusculum pióra autora Turcyk, przedmiotem analizy będzie obecność jego osoby w dwóch dziełach Herbesta. Pierwsze z tych dzieł narzuca się samo,

9 A. Werpachowska, Z dziejów retoryki..., zwł. s. 124-132. Zob. również J.Z. Lichański, Polski wkład $w$ badania nad stylistyka i składniq oraz rytmika prozy w wieku XVI, w: idem, Retoryka w Polsce. Studia o historii, nauczaniu i teorii w czasach I Rzeczypospolitej, Warszawa 2003, s. 33-58, także idem, Recepcja retorów greckich w Polsce w XVI i XVII wieku w nauczaniu szkolnym. Rekonesans, w: Retoryka antyczna i jej dziedzictwo, red. M. Grzesiowski, Warszawa 1996, s. 115-126.

10 Górski cytuje wyimek z listu Orzechowskiego skierowanego do siebie w dedykacji Dissertatio: „Benedictus Herbestus, quod paene praeterieram ex itinere, hinc ad vos rediens cum Gregorio Samboritano, scripserat ad me schedulam suamque De periodo disputationem ad me miserat, sententiam pertentans meam. Huic ego privatim nihil respondi” [„Benedykt Herbest - że nieco zejdę z drogi wracając stąd do was z Grzegorzem z Sambora, napisał do mnie liścik i wraz ze swą Rozprawa o periodach przesłał go do mnie, zabiegajac o moje zdanie. Osobiście nic mu na to nie odpowiedziałem"], S. Orzechowski, Dissertatio Laurentii Siradiensis, Kraków: Łazarz Andrysowic, 1563, $\mathrm{B}_{\mathrm{v}}-\mathrm{Bii}_{\mathrm{r}}$. 
gdyż pozostaje bezpośrednio związane ze sporem. Jest to oczywiście ukończony w 1565 roku i wydany w Lipsku rok później podręcznik Periodicae responsionis libri $V$. Zawiera on ostateczną odpowiedź Herbesta, podówczas nauczyciela w poznańskiej Akademii Lubrańskiego, na refutację Górskiego. Ze względu na publikację w momencie, gdy spór już przygasł, i brak odpowiedzi na to pismo ze strony Górskiego, można w Periodicae responsionis upatrywać pierwszego ogniwa w łańcuchu kształtowania pamięci o krakowskim konflikcie. Traktat jest dedykowany wybitnym pisarzom: Piotrowi Skardze, Andrzejowi Patrycemu Nideckiemu oraz na pierwszym miejscu Stanisławowi Orzechowskiemu jako uczonym mężom wybranym do rozsądzenia sporu ${ }^{11}$. Dedykacja obfituje w topikę pochwalną eksponującą ich intelektualne kompetencje oraz - co ważne w kontekście temperatury sporu - ich bezstronność. Nie jest to jednak tekst, który przykuwałby uwagę czytelnika szczególnym ukształcaniem elokucyjnym albo wyjątkowo pomysłową inwencją.

Trzy pierwsze księgi dzieła Herbest poświęcił pełnemu i najbardziej przemyślanemu przedstawieniu swojej teorii periodu, w kolejnych dwóch przedstawił przebieg sporu z Górskim. Szczególnie dużo miejsca poświęcił rozliczeniu swojego przeciwnika $\mathrm{z}$ argumentów niemerytorycznych. Podręcznik ten uzupełniony został indeksem, w którym znajdujemy nazwisko Orzechowskiego, nie jednak w roli niesprawiedliwego sędziego, lecz człowieka, którego spotkała krzywda ze strony złego redaktora jego pism, czyli Jakuba Górskiego. Herbest zarzuca Górskiemu psucie łaciny autora Chimery i w ten sposób włącza Orzechowskiego w rozważania zawarte w rozdziale dotyczącym podziału okresów na gramatyczne i retoryczne. Zarzut ma związek z peroratio i foniczną dysfunkcjonalnością interpunkcji

11 B. Herbest, Periodicae responsionis libri V, Lipsk 1566, k. $)_{\mathrm{r}}$ : „Ad Stanislaum Orichovium, Andream Patritium et Petrum Scargonem, viros eloquentiae gloria claros iudicesque ad causam periodicam electos, B[enedicti] Herbesti prooemium”. [„Przedmowa Benedykta Herbesta do Stanisława Orzechowskiego, Andrzeja Patrycego i Piotra Skargi, mężów sławnych chwałą wymowy i sędziów wybranych do rozsądzenia sporu o periody"]. 
Górskiego. Przytoczmy charakterystyczny argument „z Orzechowskiego":

bonum artificem bonum opus facere; te vero, quia bonus artifex non es, etiam ex Orichovianis bonis latina facere non bona. Non mea tantum haec est de punctis tuis sententia; quaere etiam ab illis, qui tibi non assentari, sed liberum facere iudicium, norunt. Audies eos mirari vehementer, qui fiat; quod tu, qui de periodis scripsisti, tua punctorum distinctione tuam obscures distinctionem, maiori autem hoc illis esse admirationi cognosces; quod Stanislai Orichovii, doctissimi et eloquentissimi viri perspicua scripta, quae tuam habent notarum distinctionem inter legendum obscura esse videantur. Tuum hoc est vitium, qui corrector fuisti, non authoris Orichoviii. Hoc ex me audiverunt auditores in auditorio publico, non est, quod in me falso Orichovii nostratis odium concites ${ }^{12}$.

[Dobry autor tworzy dobre dzieło. Ty zaś, ponieważ nie jesteś dobrym autorem, robisz nawet $\mathrm{z}$ dobrej łaciny Orzechowskiego niedobrą. To nie jest tylko moje zdanie o twoim przestankowaniu. Zapytaj także tych, którzy potrafią nie przytakiwać ci, lecz przedstawić niezależny osąd. Posłuchaj tych dziwiących się bardzo, dlaczego tak się dzieje, że ty, który pisałeś o okresach, zaciemniasz swym rozróżnieniem znaków przestankowych swe rozróżnienie. Zrozumiesz, że jeszcze większe jest ich zdziwienie, że jasne pisma Stanisławowa Orzechowskiego, męża bardzo uczonego i wymownego, które zawierają twoje rozróżnienie znaków, wydają się być w trakcie czytania niejasne. To jest twoja wina, który byłeś ich korektorem, nie autora Orzechowskiego. To usłyszeli ode mnie słuchacze na publicznym posiedzeniu, nie zaś to, że wzniecasz przeciw mnie bezpodstawnie niechęć Orzechowskiego, mojego krajana.]

Herbestowi zależało szczególnie na pozytywnej opinii Orzechowskiego i wysoko cenił jego kunszt pisarski. Być może także chciał $\mathrm{w}$ ten sposób podważyć znaczenie wzięcia przez Okszyca strony Górskiego. Może chciał też pokazać, że wyczucie dobrej łaciny nie jest u Górskiego tak dobre, jak sam mniema, gdyż źle wydaje polskiego Cycerona. Jakże może zatem rozumieć dobrze teksty samego Arpinaty? We wnioskach podkreśla jedynie skuteczność własnej ar-

12 Ibidem, k. Qq6 - Qq7. 
gumentacji i zwraca uwagę na błędną interpunkcję oraz brak rozróżnienia między periodem gramatycznym i retorycznym u swego starszego kolegi, które zaciemniają sens redagowanych przez niego dzieł.

Szacunek dla rzekomo psutej przez Górskiego Latinitas nie jest wszakże jedynym Okszycowym wątkiem w późniejszej twórczości pedagoga $z$ Nowego Miasta. Herbest pozostawił bowiem po sobie ciekawą samą w sobie relację z podróży na Ruś, którą odbył wiosną 1566 roku. W trakcie owej peregrynacji złożył wizytę autorowi Quincunksa. Podróż trwała kilka miesięcy i została przedstawiona w Wypisaniu drogi, dodatku do Chrześcijańskiej porządnej odpowiedzi $i^{13 .}$ Wyłaniający się z tego tekstu obraz Orzechowskiego nie do końca przystaje do "podręcznikowego" odczytania spraw i żywota proboszcza z Żurawic. Relacja ma wymiar ekumeniczno-misyjny nawiązujący do myśli Orzechowskiego o Kościołach wschodnich, mówi o szansach przywrócenia pełnej jedności z Ormianami i prawosławnymi ${ }^{14}$. Herbest sporo uwagi poświęcił też perspektywom nawracania wyznawców judaizmu ${ }^{15}$. Wypisanie drogi zawiera też zaskakujący w kontekście opisu podróży ekskurs historiozoficzny o powodach odkrycia Ameryki. Doszło do tego zdaniem autora w wyniku porzucenia przez ludzi na obszarze dawnej christianitatis prawdziwej wiary, czego skutkiem było poszukiwanie przez Boga nowych ludów ${ }^{16}$.

13 Por. B. Kosmanowa, Wróg celibatu. Stanisław Orzechowski, Warszawa 1971, s. 270; A. Maczuga, Ostatnie lata w życiu Stanisława Orzechowskiego (1562-1566) na podstawie Orichovianów wydanych przez J. Korzeniowskiego w Krakowie, Kraków 1895; K. Koehler, Stanisław Orzechowski i dylematy humanizmu renesansowego, Kraków 2004, s. 521. Tekst podaję za pierwodrukiem, uwspółcześniając pisownię: B. Herbest, Wypisanie drogi, w: idem, Chrześcijańska porządna odpowiedź..., Kraków: Mateusz Siebeneycher, 1567, k. Yyviii-Aaavi. Starnawski, przytaczając fragment o Orzechowskim, oparł się na innym wydawcy C. Studynskij, Zarys dziejów sławy i naukowego poznania Orzechowskiego, w: idem, Odrodzenie. Czasyludzie - książki, Łódź, 1991, s. 167-168 i odpowiednie przypisy.

14 B. Herbest, Wypisanie drogi..., k. Zzv i n. Por. A. Kaim, Ekumenia w dobie renesansu. Jedność kościoła w ujęciu Stanisława Orzechowskiego, Lublin 2002.

15 B. Herbest, Wypisanie drogi..., k. Aaav .

16 Ibidem, k. Aaaii. 
Najciekawiej dla nas przedstawiają się portrety zaangażowanych w restytucję katolicyzmu humanistów, które pojawiają się w tekście Herbesta. Obok Orzechowskiego został wymieniony kardynał Hozjusz:

Piszą to o Sokratesie, iż go nigdy nic nie obruszyło, ani szczęście, ani przeciwność; we dwóch też naszych biskupach w drugim ks. Hosiusie kardynale przypatrywałem się i ja temu, co to jest idem vultus eademque mens [„to samo oblicze, ten sam umysł" ${ }^{17}$. Miał natenczas ksiądz biskup scjatykę jakoby jej nie miał; wszystko u niego za jedno było. Nazajutrz po nas wyjechał on na sejm lubelski, a myśmy do Przemyśla przyjechali na dzień wielebnego św. Stanisława ${ }^{18}$.

Przyrównanie postawy wobec zmiennych kolei losu (niezależnie od tego, czy owa scjatyka, rwa kulszowa, była jedynie metaforyczna - troski związane z sejmem - czy też faktyczna) Hozjusza i Sokratesa nie jest może pomysłem wyjątkowo odkrywczym. Wskazując jednak na niezłomność postawy kardynała, autor buduje opozycję między hierarchą a bardziej poplątanymi ścieżkami życiowymi Orzechowskiego. Sądzę, że również brevitas (jedna z „kardynalnych” cnót wstępu) tego opisu pozwala go uznać za wprowadzenie do ekskursu o Orzechowskim. Napięcie między dwoma typami osobowości polskiego katolicyzmu XVI stulecia jest podkreślone przez odmiennie ukształtowane przedstawienie nowego bohatera. Zostało ono umieszczone zaraz po przytoczonych wyżej słowach:

tam zastaliśmy onego dobrze uczonego i szlachetnego człowieka, który i pisaniem, i przykładem swoim wiele ludzi do Kościoła powszechnego za sobą wiódł. Dorozumie się każdy, o kim mówię; znali dobrze i obcy ludzie Stanisława Orzechowskiego, filozofa, wymówcę i teologa wielkiego, z niemałym żalem naszym teraz niedawno zmarłego ${ }^{19}$.

17 Nawiązanie do słów Cycerona, De officiis, I. 26.2: „praeclaraque est aequabilitas in omni vita et idem semper vultus eademque frons".

18 B. Herbest, Wypisanie drogi..., k. Zziii.

19 Ibidem, k. Zziii ${ }_{\mathrm{r}}-Z_{\text {Ziii }}$. 
Początek wspomnienia o kolejach życia zmarłego kanonika przemyskiego $\mathrm{w}$ związku z zastosowanym opóźnieniem wyjaśnienia, kim jest bohater, pełni, jakby się mogło zdawać, przede wszystkim funkcję utrzymania narracyjnego napięcia. $Z$ drugiej strony to ogóle przedstawienie („zastaliśmy onego dobrze uczonego i szlachetnego człowieka, który i pisaniem, i przykładem swoim wiele ludzi do Kościoła powszechnego za sobą wiódł") przypomina do pewnego stopnia początek eposu ${ }^{20}$. Ta reminiscencja pozwala Herberstowi wydobyć z biografii Orzechowskiego sens uniwersalny. Warto zwrócić uwagę, że według Krzysztofa Koehlera egzemplaryczne czytanie własnego żywota jest cechą charakterystyczną autobiograficznego wymiaru pisarstwa Orzechowskiego ${ }^{21}$. Tekst Herbesta mógłby stanowić argument na rzecz trafności tego odczytania, zwłaszcza że ewidentnie stanowi kontynuację takiej praktyki. Co więcej, sugeruje on za pośrednictwem strukturalnej reminiscencji kontekst epicki. Filozof nie jest tutaj raczej przywołaniem postaci Wawrzyńca z Sieradza (a jeśli tak to bardzo dalekim), lecz przypomina o metodologicznych dokonaniach autora Chimery w tworzeniu własnej filozofii politycznej i teologii.

Po wprowadzeniu następuje opowieść o pozostałych dokonaniach i sprawach Orzechowskiego: obronie papieża, zmianie głoszonych poglądów (która ciężko przychodzi ludziom uczonym), utracie łaski (i pensji) „nowowierników”, pracy misyjnej wśród ruskich rodzin ziemiańskich, za którą nie otrzymał, bo nie mógł, uznania małżeństwa, o co zabiegał. Czymże był powodowany, jeśli nie dobrem duszy swojej, zauważa Herbest. Podkreśla też sprawiedliwość Okszyca, krytykującego zepsucie obyczajów w Kościele. Skupiać miał się na sprawach najistotniejszych, w jasny sposób przestrzega-

20 J. Ziomek, Sarbiewski jako krytyk Todorova, „Teksty” 1978, z. 2, s. 5-28.

21 Por. np. interpretację korespondencji z Dudyczem - K. Koehler, Stanisław Orzechowski..., s. 539 i n. 
jąc i broniąc prawdy ${ }^{22}$. Dostrzega w tym działanie opatrzności Bożej, przyrównując Rusina do szeregu upadłych sług Bożych:

Dał Pan Bóg podporę w grzech upadłym ludziom, upadek niegdy Dawidów, którego on królem i prorokiem będąc, w psalmiech swych pisać nie wstydził się; św. Paweł też, Pana Chrystusów apostoł, swoje bluźnierstwa i prześladowanie Kościoła Pańskiego w piśmie swym wspomina, także i naszym Polakom miłym Pan Bóg dał znaczny przykład Stanisława Orzechowskiego, który też przed wszystkim światem grzech swój w swoich księgach obwoływa: „Panie Boże tylko daj, aby ci, którym tego jest potrzeba, słyszeć to i widzieć chcieli!"’23.

Najciekawiej przedstawia się zakończenie Herbestowej relacji czy raczej pośmiertnego wspomnienia o Orzechowskim. Rzadki to przykład pisarza staropolskiego uwiecznionego przy lekturze:

Gdyby to oni czynili, a czynić umieli i chcieli, co Pan Bóg dał był Orzechowskiemu, naleźliby prawdę; do starych doktorów trzeba się udać temu, kto zbłądzić nie chce; nad św. Hieronimem i on wtenczas siedział, gdyśmy do Przemyśla przyjechali. A któreż księgi czytał wonczas? Te, w których tak jest napisano: „Scripturae intelligentiam absque Dei gratia et doctrina maiorum sibi imperitissimi vel maxime vendicant” [ „najbardziej nieuczeni przypisują sobie rozumienie Pisma bez łaski Bożej i nauki poprzedników"] ${ }^{24}$.

Przywołany tu obraz żywo przypomina ikonografię przedstawień humanistów w pracowni ${ }^{25}$. Choć nie można udowodnić z całą pew-

22 B. Herbest, Wypisanie drogi..., k. Zziii $-Z_{\mathrm{v}}$ Zziiii $_{\mathrm{r}}$.

23 Ibidem, k. Zziiii $-Z_{\mathrm{r}}$ Zziiii $_{\mathrm{v}}$.

24 Ibidem, k. Zziiii. Cytat to zniekształcony fragment z komentarza św. Hieronima do Księgi Daniela 11, 44-45.

25 Zob. J. Gruchała, Iucunda familia librorum. Humaniści renesansowi w świecie książki, Kraków 2002, szczególnie rozdział Humanista w pracowni, s. 131 n. oraz Amatorski rekonesans $w$ National Gallery, s. 161 n. Dodać można, że nie bez znaczenia jest wskazanie na lekturę tekstu św. Hieronima, autora niezwykle ważnego $\mathrm{w}$ strategiach humanistycznej autokreacji męża uczonego, zob. L. Jardine, The In(de)scribable Aura of Scholar-Saint in His Study. Erasmus's "Life” and "Letters" of St. Jerome, w: eadem, Erasmus, Man of Letters. The Construction of Charisma in Print, Princeton, NJ, 1995, s. 55-82. 
nością, że to akurat ta tradycja zadecydowała o takim, a nie innym ujęciu ostatniej sceny opowieści o Okszycu, powszechne oddziaływanie plastycznego języka symbolicznego na wyobraźnię (a zatem także na inwencję) twórców ówczesnych ${ }^{26}$ pozwala uznać taką hipotezę za wysoce prawdopodobną. Domaga się jeszcze odpowiedzi pytanie, czy można mówić w przypadku tej relacji o tekstowym uobecnieniu ${ }^{27}$ Orzechowskiego, a jeśli tak, to jakiego rodzaju? Za swoiście pojęte uobecnienie można uznać poniekąd nawiązanie w misyjnej części relacji do Orzechowskiego jako patrona myślenia ekumenicznego, o czym wspomniałem już wyżej. Niemniej chyba większe podstawy do tego daje wpisanie strawionego na sporach pisarza w konwencję epicką (podkreślono tu humanistyczny rodzaj agonu „pisaniem i przykładem”) oraz uznanie drogi Orzechowskiego za przykład dany grzesznym przez Opatrzność, co wzmacniają paralele biblijne - przyrównanie do króla Dawida i św. Pawła.

Zostawił nam zatem Herbest $\mathrm{w}$ relacji $\mathrm{z}$ wizyty $\mathrm{w}$ rodzinnych stronach nie tylko egzemplum dla błądzących, lecz również portret humanisty w pracowni zajętego lekturą. Jest to nie tyle instrumentalnie ideologiczny biogram sławnego pisarza, przytoczony w celu budowania w wierze czytelnika, ile raczej żywy obraz egzystencjalnych agonów Orzechowskiego, uobecniający w pewnym stopniu jego osobę w tekście. Najlepszym zaś dowodem na poważne potraktowanie Orzechowskiego jest kontynuacja niektórych wątków myśli Okszycowej w dalszych partiach tekstu. Wydaje się, że Okszyc był zbyt ważny jako autorytet i ideowy sojusznik dla Herbesta, aby polemizował z jego osądem w sporze retorycznym z Górskim. Ta strategiczna niepamięć o wyroku „Wawrzyńca z Sieradza” jest wielce charakterystycznym rysem etosu intelektualnego Herbesta. Reasumując, pisarz z Nowego Miasta przemilczał wyrok Okszyca w retorycznym

26 Zob. A. Borowski, Cesare Ripa czyli muzeum wyobraźni, w: C. Ripa, Ikonologia, przeł. I. Kania, Kraków 2004, s. V-XIII.

27 Zob. J. Domański, Tekst jako uobecnienie. Szkic z dziejów myśli o piśmie i książce, wyd. 2, Kęty 2002. 
sporze, widząc w swojej metodzie konstrukcji periodów lepszy od zaproponowanego przez Górskiego zapis stylu autora Chimery. Kolejnym powodem do niechowania urazy za pisemko „Wawrzyńca z Sieradza" był żywy oddźwięk, jaki miała w działalności Herbesta wizja koegzystencji katolicyzmu $z$ wyznaniami wschodnimi i walki $z$ protestantami proponowana przez Orzechowskiego. Przemilczenie roli tego ostatniego jako arbitra w dyspucie z Górskim miało zatem głębsze powody niż bezradność w obliczu przegranej.

\section{Szymon Starowolski}

Prace Szymona Starowolskiego są przełomowe dla dziejów literatury staropolskiej ${ }^{28}$. Przygotowane jako swego rodzaju zestaw prospektów reklamowych dla zagranicznych wydawców Setnik pisarzów polskich oraz dzieło O znakomitych mówcach Sarmacji stanowią bogaty skarbiec informacji skądinąd nieznanych. Tutaj interesować nas będą przede wszystkim zawarte w biogramach uczestników sporu uwagi o jego przebiegu, a także kryteria, jakimi posłużył się krakowski polihistor, opisując tę dysputę. Dodatkowym argumentem przemawiającym za wyborem Starowolskiego na nosiciela „pamięci o sporze” jest jego przywiązanie do tradycji intelektualnych Akademii Krakowskiej. Czy jednak można mówić o pamięci w przypadku autora, który urodził się trzy lata po śmierci Górskiego, a w chwili śmierci Herbesta miał zaledwie dziesięć lat? Czy nie lepiej w takim razie mówić o recepcji? Choć to może kontrowersyjne, obstawałbym za pamięcią, recepcja bowiem sugerować by mogła zerwanie ciągłości, poczucie obcości autora wobec opisywanych zdarzeń i osób. Tymczasem Starowolski czuł się częścią tej samej tradycji „sarmackiego” życia intelektualnego. Zasadne wydaje się przeto uznanie jego uwag

28 Są cezurą w syntezie J. Starnawskiego Dzieje wiedzy o literaturze polskiej do końca wieku XVIII, Wrocław 1984. 
za wyraz pamięci intelektualnego środowiska Krakowa o sporze ${ }^{29}$. Przyjrzyjmy się najpierw wyimkom z Hekatontas:

Jakub Górski. Chociaż zrodzony pod surowym niebem Mazowsza, od dziecka tak był zaprawiony w naukach wyzwolonych, że w siedemnastym roku życia otrzymał bardzo zasłużenie w Akademii Krakowskiej pierwszy wawrzyn, dodając do szlachetności swego rodu także szlachetność własnej cnoty, którą zawdzięczał obyczajom i nauce pobożnych doktorów Akade$\mathrm{mii}^{30}$.

Zaskakiwać może trochę, że biogram otwiera anegdotyczna wzmianka o braku negatywnego wpływu klimatu mazowieckiego na wykształcenie młodego Górskiego. Z jednej strony sam humanista mógł władać, jak się zdaje, „mazurską” polszczyzną, z drugiej - Mazowsze jako takie nie cieszyło się dobrą opinią mieszkańców innych prowincji dawnej Rzeczypospolitej ${ }^{31}$. Zwraca też uwagę podkreślenie szlachectwa pochodzącego $\mathrm{z}$ cnót nabytych $\mathrm{w}$ procesie eduka$\mathrm{cji}^{32}$. Dalej biografista opisuje karierę akademicką Górskiego, pisze o postępach w grece i zamiłowaniu do pracy dydaktycznej, której nie

29 Dodajmy, że niebezzasadnie na Starowolskiego jako kontynuatora realizacji idei tekstowego uobecnienia wskazuje J. Domański, Tekst jako uobecnienie..., s. 12, przyp. 1. Wskazana przez Domańskiego książka Szydłowskiego zawiera szczegółowe analizy kryteriów: wyznania, wykształcenia i twórczości umysłowej (podzielonej na kategorie: wykształcenia, czynów, „pomników”, „sławy”, „nieśmiertelności”, „pamięci”, „imienia”, „potomności” i „potomnych”) w ocenie autorów umieszczonych w katalogach Starowolskiego, zob. P. Szydłowski, Między renesansem a kontrreformacją. Poglądy filozoficzne Szymona Starowolskiego 1588-1656, Warszawa 1978, rozdz. Filozoficzna antropologia Szymona Starowolskiego, s. 49-110.

30 Sz. Starowolski, Setnik pisarzów polskich albo pochwały i żywoty stu najznakomitszych pisarzów polskich, przeł. i oprac. J. Starnawski, Kraków 1970, s. 88.

31 Zob. A. Nowicka-Jeżowa, Związki umysłowe Mazowsza i mazowszan $z$ Krakowem $w$ dobie Renesansu, w: Cracovia litterarum. Kultura umysłowa i literacka Krakowa i Małopolski $w$ dobie Renesansu, red. T. Ulewicz, Kraków 1991, s. 543-577.

32 Por. N. Elias, Przemiany obyczajów w cywilizacji Zachodu, przeł. T. Zabłudowski, Warszawa 1980. Dla Eliasa napięcie między szlachectwem herbowym i wywodzącym się z uprawiania sztuk wyzwolonych stanowi jeden z motorów procesu cywilizacji. 
zarzucił mimo uzyskania godności archiprezbitera, zapewniającej dochody wystarczające do utrzymania ${ }^{33}$.

Po pochwale niezrównanej biegłości Górskiego w prawach cywilnym i kanonicznym Starowolski wymienia dzieła retoryczne krakowskiego profesora:

Dowodem tego są prace napisane i wydane: O okresach; Figury gramatyczne i retoryczne; O rodzajach wymowy. Postarał się o wydanie ich drukiem po wielu publicznych rozprawach, w których walczył o palmę pierwszeństwa w dziedzinie wymowy z Benedyktem Herbestem. Na temat tego sporu zobacz piękną rozprawę Wawrzyńca z Sieradza, również akademika krakowskiego $^{34}$.

Zauważmy, że krakowski agon „o palmę pierwszeństwa w dziedzinie wymowy” dwóch krakowskich profesorów został przedstawiony zgodnie $\mathrm{z}$ przeważającą ówcześnie opinią jako wydarzenie chwalebne. Rozszerza przy tym spór o periody (dwa zasadnicze dzieła $\mathrm{z}$ obu stron i jedną dysputę) do całej teorii wymowy (wyliczone dzieła) oraz całej serii dysput. Co ciekawe, w celu poznania owego sporu odsyła czytelnika do dziełka Orzechowskiego. Mimo że przypisanie utworu Wawrzyńcowi z Sieradza, wobec ujawnienia jego prawdziwego autorstwa w liście dedykacyjnym Górskiego, to pomyłka rzeczowa, to sąd o samym opusculum - zdawałoby się wyrażona krótkim epitetem w nocie marginalnej pochwała - nie musi oznaczać jedynie chęci dodania splendoru samemu sporowi i krakowskiemu środowisku akademickiemu. Może również sugerować,

33 Sz. Starowolski, Setnik pisarzów..., s. 89.

34 Ibidem. Pisze też Starowolski o podziwie Górskiego dla Okszyca: „Szanował wszystkich pisarzy; wielbił zwłaszcza - jak ojca i mistrza - naszego Orzechowskiego, zwanego z powodu znakomitej płynności języka łacińskim Demostenesem”. Zwracał się też do niego Górski po wiadomości z zakresu retoryki - zob. T. Sinko, Erudycja klasyczna Orzechowskiego, Kraków 1939, s. 19; S. Orzechowski, Orichoviana. Opera inedita et epistulae Stanislai Orzechowski 1543-1566, vol. 1, ed. J. Korzeniowski, Kraków 1891, s. 517. 
że pewne idee, które pojawiły się na kartach rozprawy, Starowolski odczuwał jako sobie bliskie.

Przypatrzmy się z kolei charakterystyce przeciwnika Górskiego:

Benedykt Herbest. Mąż niewątpliwie wybitnego, niemal boskiego umysłu, który chciał zajaśnieć pośród swych współczesnych w Akademii nowym rodzajem wymowy. Rodem był z Rusi, przybraną ojczyznę miał w Neapolu, zwanym powszechnie Nowym Miastem ${ }^{35}$.

Siedemnastowieczny polihistor wychwycił dobrze zasadniczy powód do dumy, jaki przypisywał sobie Herbest - samodzielne opracowanie zagadnienia rytmicznego kształtu prozy. Zdanie o miejscu pochodzenia Herbesta przytoczone tutaj zostało nie dla zachowania symetrii względem Górskiego, ale z powodu pozytywnej oceny trafności oddania Nowego Miasta po grecku (Neapol), co - jak wiadomo - było z jednym $\mathrm{z}$ argumentów Górskiego ad hominem.

Sam spór został opisany szerzej niż w biogramie Górskiego:

niebawem [Herbest] stał się w wymowie współzawodnikiem Jakuba Górskiego starszego. Wyzwał kolegę i wobec całej Akademii stoczył z nim walkę o pierwszeństwo. Wreszcie pokonany całą tę dysputę o okresach i o sposobie pisania kazań wraz z argumentami swojego przeciwnika ogłosił drukiem, oddając pod sąd potomności. Jest to naprawdę znakomite dzieło i obu przeciwników należy podziwiać. Podniecony powodzeniem tego dzieła napisał Dialog o najlepszym sposobie przemawiania ${ }^{36}$, w którym usiłuje dowieść swej wyższości nawet w poprzedniej dyspucie. (...) każdy z nich zaś uważał Cycerona za swojego mistrza. Wreszcie ponieważ prawie wszyscy przyznawali Górskiemu pierwszeństwo w wymowie, Herbest złożył na ręce rektora Akademii rezygnację ze stanowiska profesora ${ }^{37}$.

Opowieść krakowskiego polihistora o sporze opisuje przede wszystkim postępowanie obu retorów, nie wprowadza jednak do jego meritum. Starowolski przedstawia zatem ciąg zdarzeń, mniej lub

35 Sz. Starowolski, Setnik pisarzów..., s. 146.

36 Możliwe, że autor ma na myśli dialog Aequus iudex.

37 Sz. Starowolski, Setnik pisarzów..., s. 147. 
bardziej zgodnych ze stanem naszej wiedzy o konflikcie, które swobodnie można zaliczyć do „humanistycznych praktyk i ceremonii” ${ }^{38}$. Postępowanie w tychże praktykach okazuje się tutaj podstawowym kryterium oceny Herbesta. Ten etyczny horyzont ulega jeszcze wzmocnieniu poprzez połączenie biogramów antagonistów w $D e$ claris oratoribus Sarmatiae:

Aby zaś jedno miejsce połączyło dwu nieprzejednanych niegdyś przeciwników, wspomnę tu Jakuba Górskiego i Benedykta Herbesta. Górski zajmuje wśród mówców Akademii Krakowskiej najwyższe miejsce w dziedzinie wymowy (w co żaden Sarmata nie wątpi), a najbliższe mu wydaje się dzierżyć Herbest. Tocząc ze sobą ów słynny spór, całą niemal Polskę zarzucili wieloma wymierzonymi w siebie pisemkami o sztuce wymowy i stoczyli wiele sławnych dysput ${ }^{39}$.

Starowolski był kontynuatorem humanistycznego żywotopisarstwa. Świadczy o tym nie tylko docenienie rangi sporu retorycznego i roli obu antagonistów w życiu intelektualnym kraju, w którym wymowa zajmowała tak poczesne miejsce, ale również zaczerpnięcie

38 Jest to jeden $\mathrm{z}$ typów źródeł do poznania humanistycznej formacji intelektualnej, które wymienił Jerzy Axer w referacie Respublica Polonorum versus Respublica Litteraria Europaea na zorganizowanej przez Katedrę Literatury Staropolskiej UJ w dniach 19-21 października 2005 w Krakowie konferencji „Humanizm i Renesans. Rewizje metodologiczne z perspektywy półwiecza”. Będąca pokłosiem tej sesji publikacja Renaissance and Humanism from the Central-East European Point of View, red. G. Urban-Godziek, Kraków 2014 zawiera artykuł J. Axera, lecz na inny temat, Latinitas Polonorum or Pedantry à la polonaise, s. 153163. Dobre pojęcie o roli humanistycznych praktyk i ceremonii daje np. J. Glomski, Patronage and Humanist Literature in the Age of the Jagiellons: Court and Career in the Writings of Rudolf Agricola Junior, Valentin Eck and Leonard Cox, Toronto 2007; E. Bernstein, Group Identity Formation in the German Renaissance Humanists: The Function of Latin, w: Germania latina, Latinitas teutonica: Politik, Wissenschaft, humanistische Kultur vom späten Mittelalter bis in unsere Zeit, Hg. von E. Keßler, H.C. Kuhn, Bd. 1, München 2003, s. 375-386.

39 Sz. Starowolski, O znakomitych mówcach Sarmacji, przeł. i oprac. E.J. Głębicka, Warszawa 2002, s. 53. Podstawa łacińska, s. 52. Nb. Herbest z Górskim są „sąsiadami” Orzechowskiego i Frycza. 
sposobu ich opisu z Rerum memorandum libri Petrarki ${ }^{40}$. Cóż może bowiem świadczyć lepiej o przekonaniu o dziedziczeniu tradycji antycznej niż użycie wobec naszych autorów słów autora poematu Africa piszącego o Demostenesie i Ajschinesie?

Dla Starowolskiego spór Górskiego z Herbestem to przede wszystkim przykład dynamicznego życia intelektualnego Krakowa oraz całej Polski. W rezultacie spór stanowi chwalebne wydarzenie, które wpisuje się w dzieje rodzimej erudycji (opisanej w Setniku), bądź w serię sławnych potyczek oratorskich (De claris oratoribus Sarmatiae). Nie jest w związku z tym jedynie typowym sporem akademickim dotyczącym teorii retoryki. W Rzeczypospolitej ars oratoria stanowiła osnowę życia społecznego i politycznego, Starowolski zaś, promując osiągnięcia rodzimych nauczycieli sztuki wymowy, dodaje temu sarmackiemu upodobaniu do retoryki aury uczoności.

\section{Franciszek Ryszard Goezius}

Wiek XVIII był w kulturze polskiej czasem wykuwania się kanonu literatury polskiej; był to również okres wzmożonego wydawania dzieł znanych dotychczas z rękopisów oraz wznawiania druków. Stało za tym między innymi pragnienie dostarczenia czytelnikom (zwłaszcza uczniom) wzorów języka narodowego odmiennego stylistycznie od polszczyzny siedemnastowiecznej. Była to również próba przedstawienia modeli nie tylko stylistycznych, ale i osobowych. Zwłaszcza ta druga przesłanka, przy całej rewerencji wydawcy dla stylu Stanisława Orzechowskiego, kierowała Franciszkiem Bohomolcem, gdy przygotowywał do druku Żywot i śmierć Jana Tarnowskiego ${ }^{41}$. Tekst

40 Zwróciła na to uwagę E.J. Głębicka w wydaniu krytycznym dzieła Starowolskiego zob. O znakomitych mówcach..., Wstęp, s. 7; komentarze, s. 111.

${ }_{41}$ Zob. F. Bohomolec, Przedmowa, w: S. Orzechowski, Żywot i śmierć Jana Tarnowskiego, Sanok 1855, s. 5-31. Charakterystyczne, że przedmowę otwiera pochwa- 
został przez wydawcę poprzedzony przedmową, która zawiera informacje o życiu Orzechowskiego oraz Jakuba Górskiego. Informacja o humaniście z Mazowsza została zamieszczona, ponieważ do niego zwraca się autor na początku $\dot{Z} y w o t a^{42}$. Wartość tej editio princeps nie wytrzymała próby czasu, co z właściwą sobie filologiczną skrupulatnością wykazał współczesny wydawca Żywota Jerzy Starnawski, ujawniając liczne usterki tekstologiczne i dowolne zmiany lekcji poszczególnych wyrazów w wydaniu Bohomolcowym ${ }^{43}$. Może zastanawiać i dodatkowo zmniejszać naszą wiarę w edytorską solidność byłego jezuity okoliczność, że zestawiając informacje o dwóch przyjaciołach, Górskim i Orzechowskim, nie zwrócił uwagi na udział tego ostatniego w interesującym nas sporze. Jest to o tyle dziwne, że wspominając o tym wydarzeniu, odsyła on do wcześniejszej o niecałe dwie dekady książeczki pióra Franciszka Ryszarda Goeziusa, z której mógł się dowiedzieć szczegółowo o przebiegu sporu. Podejrzewać można, że Bohomolec rozprawy Goeziusa nie przeczytał dokładnie lub miał o jej zawartości informacje $\mathrm{z}$ drugiej ręki ${ }^{44}$.

Przejdźmy zatem do tego źródła, czyli Goeziusowego Otium Varsaviense in selectis ex historia litteraria Poloniae argumentis ex-

ła pożytków z czytania historii, a zwłaszcza żywotów: „Historia albowiem przekłada nam rzeczy ogółem, żywoty zaś w szczególności je wyłuszczają", ibidem, s. 5. Dzieli się też z czytelnikiem informacją, że sam do czasu poznania dzieła kanonika przemyskiego nosił się z zamiarem napisania biografii Tarnowskiego.

42 „Piszesz do mnie Jakubie Górski, abym ci pogrzeb pana Jana Tarnowskiego, kasztelana krakowskiego, hetmana koronnego, nie odjeżdżając z Tarnowa łacińskim językiem wypisał. Krótki czas naznaczyłeś mi, i ku łacinie, i ku pogrzebu", S. Orzechowski, Żywot i śmierć Jana Tarnowskiego, w: idem, Wybór pism, oprac. J. Starnawski, Wrocław 1972, s. 199.

43 J. Starnawski, Zarys dziejów sławy..., s. 176. Za największą zaletę Bohomolcowej edycji uznaje współczesny wydawca wykorzystanie wcześniej znanego szerzej jedynie ze wspomnień w dziełach bibliograficznych listu Okszyca do Commendoniego. Paradoksalnie sam Bohomolec podkreślał swoją wierność rękopisowi: „postanowiłem ten sam żywot jak najprędzej wydać na światło publiczne, nie ważąc się w nim żadnego słowa, ani ortografii nawet odmieniać, gdzie ją można było zachować" F. Bohomolec, Przedmowa..., s. 7.

${ }^{44}$ Ibidem, s. 28-31. 
plicandis insumptum. Jest to przykład wczesnej historii literatury na gruncie polskim. Zawiera bardzo ciekawy zbiór rozpraw uczonego, który przyjrzał się szczególnie uważnie zagadnieniom życia literackiego dawnej Rzeczypospolitej, zwłaszcza uczonym humanistom polskim z XVI wieku. Oprócz rozdziału poświęconego konfliktowi Górskiego i Herbesta Goezius omawia wiele innych zjawisk z polskiego życia intelektualnego ${ }^{45}$. Już we wstępie autor zdradza swój stosunek do dawnego sporu. Przytoczmy tu jedno z licznych i charakterystycznych dla Goeziusa uwag: „Dolet mihi, ita vivam, scriptum, in quo disceptationes de lana caprina historia contineatur, meis ingratiis bis editum esse” [„Boleję jako żywo, że pismo, które zawiera historię sporu o kozią wełnę, ukazało się mimo mojej niechęci po raz drugi" ${ }^{46}$. Prawdopodobnie to obrazowe i deprecjonujące przysłowiowe określenie przedmiotu sporu zawdzięcza autor lekturze dzieła Jakuba Górskiego, który tak opisał lata studenckie w Akademii w swoim pierwszym dziele o periodach:

Młodość naszą, która nas do wymowy była powinna zaprawić, straciliśmy marnie albo strawiliśmy na naukach, które więcej wzgardy niż ozdoby przysporzyć nam mogły. Przypadła ona na czasy, w których najwstrętniejsze barbarzyństwo panowało samowładnie, w których łajdackie rozprawy przez ludzi czasu i rozumu nadużywających, spisane z wielką dla młodzieży do lepszych studiów uzdolnionej i Rzeczypospolitej szkodą wszędzie roz-

45 F.R. Goezius, Otium Varsaviense..., Wrocław 1755. Index: I. Diatribe de disceptatione inter Benedictum Herbestum et Iacobum Gorscium de periodis, II. Vita Andreae Patricii Livoniae Antistitis, III. De Polonorum Greacis interpretibus, IV. Petri Tomicii Episcopi Cracoviensis ad Erasmum Rotterodamum epistola nondum edita, V. De usu epistolarum in re Polonorum litteraria dissertatio, VI. Relatio de Ubaldi Mignonii Noctibus Sarmaticis et aliis contra eas editis scriptionibus. To jedyne dzieło F.R. Goeziusa znane Estreicherowi, por. K. Estreicher, Bibiliografia polska, t. XVII, Kraków 1899, s. 210. W najnowszych pracach dotyczących sporu autorstwa A. Werpachowskiej i J.Z. Lichańskiego nie znalazłem wzmianek o pracy Goeziusa. Odwołują się do niego natomiast niektórzy autorzy piszący wcześniej o sporze, np. K. Mazurkiewicz, Benedykt Herbest. Pedagog-organizator szkoły polskiej w XVI wieku. Kaznodzieja-misjonarz doby Reformacji, Poznań 1925, s. 148.

${ }_{46}$ F.R. Goezius, Otium Varsaviense..., k. ${ }^{*}{ }_{\mathrm{r}}$. 
brzmiewały. Toteż wśród rozpraw de lana caprina, jak to mówią, najlepszy czas, który można było na studia wymowy obrócić, zmarnowaliśmy. I później, jakby się należało, po części wskutek nabytego doświadczenia, po części wskutek rady nauczycieli, którzy pierwsi z tych pleśni się wyzwolili, odwróciliśmy się od tych nauk, które rozumu rozwinąć nie mogły, a zwróciliśmy się do zajęć, które wolnego człowieka przede wszystkim są godne ${ }^{47}$.

O ile można się spierać, czy przysłowiowe sformułowanie pojawia się u Goeziusa jako nawiązanie do Górskiego, o tyle nie ulega raczej wątpliwości, że ta opinia zaważyła na długo na odbiorze pism krakowskich profesorów ${ }^{48}$. Interesujące, że rozpoczynając swoją rozprawę, autor wskazuje na równolegle toczące się w Europie spory literackie, jakby antycypując temat rozprawy Stanisława Łempickiego. Górski spierał się z Herbestem podobnie jak Pietro Bembo z Giovannim Pikiem della Mirandolą o imitację, jak Angelo Poliziano z Paulusem Cortesiusem, jak Erazm z Rotterdamu z Juliuszem Cezarem Scaligerem o cyceronianizm ${ }^{49}$.

Następnie Goezius na podstawie dzieł obu autorów i Starowolskiego szczegółowo przedstawia dzieje sporu i losy jego uczestników. Poświęca też niemało miejsca omówieniu udziału Kochanowskiego i Orzechowskiego w tym uczonym agonie, rekonstruując okoliczności, w jakich doszło do wydania sądów obu pisarzy:

Gorscius quidem rem omnem ad unum Philippum Padnievium, Cracoviensem Pontificem, detulit; Herbestus autem plurium potius optavit experiri iudicium atque tres causae suae arbitros constituit, de quibus pluribus verbis agam tum, cum prius de ea concertatione Padnievio, quid visum sit, narravero. Id vero ille parvo poematio per Joannem Cochanovium, poetarum Polonorum, tum qui in patria lingua, tum qui Romana cecinissent,

47 Cytat za: K. Morawski, Jakub Górski, Humanista i apologeta, w: idem, Czasy Zygmuntowskie na tle pradów odrodzenia, Warszawa 1965, s. 116. Podstawa łacińska: J. Górski, De periodis atque numeris oratoriis libri duo, Kraków: M. Siebeneicher, $1558, \mathrm{k} . \mathrm{ii}_{\mathrm{v}}-\mathrm{iii}_{\mathrm{r}}$.

48 Zob. M. Wiszniewski, Historia literatury polskiej, t. 1, Kraków 1840, s. 111; opinia ta, zdaje się, nie była obca również Morawskiemu i Łempickiemu.

49 F.R. Goezius, Otium Varsaviense..., k. $\mathrm{A}_{\mathrm{r}}-\mathrm{A}_{\mathrm{v}}$ (k. 1-2). 
multorum iudicio principem, perscribi fecit, in eo igitur et Gorscii causam probat et eidem victoriam, quam de adversario obtinuisset, gratulatur. Editum est id poemation ab ipso Gorscio Cracoviae MDLXIII. una cum Dissertatione Laurentii Siradiensis philosophi super disputatione periodica Gorscii et Herbesti. Causam huic dissertationi praebuit ipse Herbestus; is enim suam contra Gorscium exaratam disputationem ad Stanislaum Orechovium, virum in primis saeculi sui, non Poloniae tantum, verum totius Europae oratoribus merito collocandum, misit, rogans, uti se, quid de toto illo negocio sentiret, redderet certiorem; ei quidem Orechovius ipse non respondebat, iudicium tamen suum a quodam suorum Laurentio Siradiensi dicto de ea perscriptum, Gorscio transmisit. Verum ille huius libelli scripti suspicionem in ipsum Orechovium transferre videtur, utut sit, id certe constat, eum ex eloquentissimi illius viri sententia fuisse compositum ${ }^{50}$.

[Górski zaniósł całą rzecz do jednego Filipa Padniewskiego biskupa krakowskiego, Herbest zaś chciał raczej poznać opinię kilku osób i ustanowił trzech sędziów w swojej sprawie, o których powiem w kilku słowach wtedy, gdy opowiem najpierw o tym, co sądził o tej dyspucie Padniewski. On zaś uczynił to za pomocą krótkiego poematu napisanego przez Jana Kochanowskiego zdaniem wielu ludzi księcia poetów polskich, którzy tworzyli zarówno w języku ojczystym, jak i po łacinie. Poparł w nim więc sprawę Górskiego i winszował mu tego zwycięstwa, które odniósł nad przeciwnikiem. Ten poemat został wydany przez samego Górskiego w Krakowie w 1563 roku wraz z Rozprawa Wawrzyńca $z$ Sieradza filozofa dotyczaca dysputy o periodzie Górskiego i Herbesta. Przyczyny [napisania] tej rozprawy dostarczył sam Herbest. On bowiem przesłał swą napisaną przeciw Górskiemu rozprawę do Stanisława Orzechowskiego, męża słusznie zaliczanego do największych mówców swego wieku nie tylko w Polsce, lecz w całej Europie, pytając o to, co sądził o tej sprawie, aby mógł się upewnić. Sam Orzechowski nie odpowiedział mu jednak, lecz swój sąd o niej spisany przez pewnego ze swoich ludzi zwanego Wawrzyńcem z Sieradza wysłał do Górskiego. On zaś, jak się zdaje, przeniósł na Orzechowskiego podejrzenie napisania tej książeczki; jakkolwiek było, to jest rzeczą pewną, że powstała ona dzięki opinii tego bardzo wymownego męża.]

Zarówno w tym fragmencie, jak i w innych miejscach Goezius buduje swoją narrację, opierając się na źródłach, przytaczając wy-

${ }^{50}$ Ibidem, k. A7 ${ }_{\mathrm{r}}$ (k. 13). 
imki z dzieł zaangażowanych pisarzy, odtwarzając nie tylko anegdotyczno-biograficzne wątki, ale również argumentację obu stron ${ }^{51}$. Rozprawa pozwalała korzystającym z niej badaczom zrozumieć zasadnicze punkty sporne i poznać najważniejsze fakty historyczne związane $\mathrm{z}$ dysputą. Zniechęcała jednak lekceważącym tonem wykładu do lektury samych tekstów. Jednocześnie warto zwrócić uwagę na różnicę w postawach względem przeszłości i retoryki u Starowolskiego i Goeziusa. Dla siedemnastowiecznego autora jego własna działalność jest kontynuacją tradycji intelektualnych reprezentowanych przez Górskiego i Herbesta, a otaczająca go „sarmacka” wymowa jest zbudowana na fundamentach teorii retorycznej, o które spierali się obaj krakowscy akademicy. U Goeziusa można dostrzec raczej zerwanie - spór obu humanistów należy według niego do zamkniętego rozdziału historii retoryki, gdy profesorowie tracili czas na kłótnie o „kozią wełnę”.

\section{Zakończenie}

Analizowane przykłady użycia historii sporu bądź wybiórczej o nim pamięci stanowią fragment wymownej i zmieniającej się panoramy pejzażu intelektualnego epoki staropolskiej. Z jednej strony mamy przykład selektywnego relacjonowania konfliktu. Benedykt Herbest nie chciał w swojej ostatecznej wypowiedzi na temat periodów przyznać, że jeden z jego wybranych arbitrów, Stanisław Orzechowski, wydał już swój sąd, nawet jeśli w cokolwiek osobliwej formie i pod pseudonimem. Co więcej, zarzucał on Górskiemu psucie pism łacińskich Okszyca. Sądzę, że o tym milczeniu zadecydowały nie tylko względy doraźne, ale - jak można się o tym przekonać z lektury $W y$ pisania drogi - również całościowa strategia wystąpień publicznych

${ }^{51}$ Ibidem, k. A2 i n. (k. 4 i n.). 
Herbesta jako katolickiego apologety. Autor Chimery był bowiem dla niego autorytetem.

Szymon Starowolski z kolei wpisał historię waśni akademickiej $\mathrm{w}$ wizję pewnego kontinuum uczonych Sarmatów na przestrzeni wieków. Uczynił $\mathrm{z}$ agonu wydarzenie godne pamięci potomnych i chwalebne, przydające środowisku, w którym się toczyło, żywego intelektualnie charakteru. Odmienne cele przyświecały kolejnemu z autorów. Bibliotekarz z Biblioteki Załuskich, Franciszek Ryszard Goezius, tworzył w nowo powstałym paradygmacie analizy przeszłości kulturowej - pisanej na potrzeby uczonej publiczności historia litteraria, w której liczyło się już nie tylko samo starcie dwóch uczonych, ale i wykorzystane przez nich argumenty. One też doczekały się w Otium Varsaviense obszernej eksplikacji. Jednocześnie zgodnie z duchem metaretorycznych poglądów swojej epoki bagatelizował on materię sporu. Jego lekceważenie miało duże znaczenie. Opinie te bowiem zniechęcały następne pokolenia badaczy do poważnego potraktowania meritum konfliktu między Górskim a Herbestem. Przykłady tych trzech twórców pozwalają prześledzić metamorfozy pamięci o sławnym niegdyś, a i dziś interesującym sporze krakowskich uczonych.

\section{Bibliografia}

Assmann J., Pamięć kulturowa. Pismo, zapamiętywanie i polityczna tożsamość w cywilizacjach starożytnych, przeł. A. Kryczyńska-Pham, Warszawa 2008.

Axer J., Latinitas Polonorum or Pedantry à la polonaise, w: Renaissance and Humanism from the Central-East European Point of View, ed. by G. Urban-Godziek, Kraków 2014.

Bernstein E., Group Identity Formation in the German Renaissance Humanists: The Function of Latin, w: Germania latina, Latinitas teutonica: Politik, Wissenschaft, humanistische Kultur vom späten Mittelalter bis in unsere Zeit, Hg. von E. Keßler, H.C. Kuhn, vol. 1, München 2003.

Bohomolec F., Przedmowa, w: S. Orzechowski, Żywot i śmierć Jana Tarnowskiego, Sanok 1855. 
Borowski A., Cesare Ripa czyli muzeum wyobraźni, w: C. Ripa, Ikonologia, przeł. I. Kania, Kraków 2004.

Buszewicz E., Wielcy i mali poeci w „Foricoeniach” Jana Kochanowskiego, w: Dobrym towarzyszom gwoli. Studia o „Foriceniach” i „Fraszkach” Jana Kochanowskiego, red. R. Krzywy, R. Rusnak, Warszawa 2014.

Domański J., Tekst jako uobecnienie. Szkic z dziejów myśli o piśmie i książce, wyd. 2, Kęty 2002.

Elias N., Przemiany obyczajów w cywilizacji Zachodu, przeł. T. Zabłudowski, Warszawa 1980.

Estreicher K., Bibiliografia polska, t. 17, Kraków 1899.

Glomski J., Patronage and Humanist Literature in the Age of the Jagiellons. Court and Career in the Writings of Rudolf Agricola Junior, Valentin Eck and Leonard Cox, Toronto 2007.

Goezius F.R., Otium Varsaviense in selectis ex historia litteraria Poloniae argumentis explicandis insumptum, Wrocław 1755.

Le Goff J., Historia i pamięć, przeł. A. Gronowska, J. Stryjczyk, Warszawa 2007.

Górski J., De generibus dicendi / O rodzajach wymowy, przeł. i oprac. R. Sawa, red. nauk. A. Axer, Warszawa 2010.

Górski J., De periodis atque numeris oratoriis libri duo, Kraków: Mateusz Siebeneycher, 1558.

Gruchała J., Iucunda familia librorum. Humaniści renesansowi w świecie książki, Kraków 2002.

Herbest B., Periodicae responsionis libri V, Lipsk 1566.

Herbest B., Wypisanie drogi, w: idem, Chrześcijańska porząna odpowiedź..., Kraków 1567.

Jardine L., Erasmus, Man of Letters. The Construction of Charisma in Print, Princeton, NJ, 1995.

Koehler K., Stanisław Orzechowski i dylematy humanizmu renesansowego, Kraków 2004.

Kosmanowa B., Wróg celibatu. Stanistaw Orzechowski, Warszawa 1971.

Lichański J.Z., Retoryka w Polsce. Studia o historii, nauczaniu i teorii w czasach I Rzeczypospolitej, Warszawa 2003.

Lichański J.Z., Recepcja retorów greckich $w$ Polsce $w$ XVI $i$ XVII wieku $w$ nauczaniu szkolnym. Rekonesans, w: Retoryka antyczna i jej dziedzictwo, red. M. Grzesiowski, Warszawa 1996.

Łempicki S., Spory i turnieje literackie epoki renesansu, w: idem, Wiek złoty i czasy romantyzmu w Polsce, Warszawa 1992.

Maczuga A., Ostatnie lata $w$ życiu Stanistawa Orzechowskiego (1562-1566) na podstawie Orichovianów wydanych przez J. Korzeniowskiego w Krakowie, Kraków 1895.

Mazurkiewicz K., Benedykt Herbest. Pedagog-organizator szkoły polskiej w XVI wieku. Kaznodzieja-misjonarz doby Reformacji, Poznań 1925. 
Mejor M., Jana Kochanowskiego foricenium „Ad Iacobum Gorscium”, czyli kim byt Helvidius, w: Wiazanie sobótkowe. Studia o Janie Kochanowskim, red. E. Lasocińska, W. Pawlak, Warszawa 2015.

Morawski K., Czasy Zygmuntowskie na tle prądów odrodzenia, Warszawa 1965.

Nowicka-Jeżowa A., Związki umysłowe Mazowsza i mazowszan $z$ Krakowem w dobie Renesansu, w: Cracovia litterarum. Kultura umystowa i literacka Krakowa i Małopolski w dobie Renesansu, red. T. Ulewicz, Kraków 1991.

Orzechowski S., Dissertatio Laurentii Siradiensis, Kraków 1563.

Orzechowski S., Orichoviana. Opera inedita et epistulae Stanislai Orzechowski 15431566, vol. 1, ed. J. Korzeniowski, Kraków 1891.

Orzechowski S., Wybór pism, oprac. J. Starnawski, Wrocław 1972.

Ricoeur P., Pamięć, historia, zapomnienie, przeł. J. Margański, Kraków 2006.

Sinko T., Erudycja klasyczna Orzechowskiego, Kraków 1939.

Sroczyński A., Dylematy Stanisława Orzechowskiego wobec staropolskiej kultury retorycznej, w: Literatura renesansowa w Polsce i Europie. Studia dedykowane Profesorowi Andrzejowi Borowskiemu, red. J. Niedźwiedź, Kraków 2016.

Starnawski J., Dzieje wiedzy o literaturze polskiej do końca wieku XVIII, Wrocław 1984.

Starnawski J., Zarys dziejów sławy i naukowego poznania Orzechowskiego, w: idem, Odrodzenie. Czasy - ludzie - książki, Łódź, 1991.

Starowolski Sz., O znakomitych mówcach Sarmacji, przeł. i oprac. E.J. Głębicka, Warszawa 2002.

Starowolski Sz., Setnik pisarzów polskich albo pochwały i żywoty stu najznakomitszych pisarzów polskich, przeł. i oprac. J. Starnawski, Kraków 1970.

Szydłowski P., Między renesansem a kontrreformacja. Poglady filozoficzne Szymona Starowolskiego 1588-1656, Warszawa 1978.

Werpachowska A., Z dziejów retoryki XVI wieku. Polemika Jakuba Górskiego z Benedyktem Herbestem, Wrocław 1987.

Wiszniewski M., Historia literatury polskiej, t. 1, Kraków 1840.

Ziomek J., Sarbiewski jako krytyk Todorova, „Teksty” 1978, z. 2. 